\title{
FACE-TO-FACE TANDEM AND ETANDEM: DIFFERENCES THAT INFLUENCE THE MAINTENANCE OF TANDEM-LEARNING ACTIVITIES
}

\section{Tandem face a face e eTandem: diferenças que influenciam a manutenção de atividades de aprendizagem em tandem}

Abstract | This paper compared two qualitative multiple case studies and discussed the influence that face-toface tandem and eTandem methods had on maintaining learning activities in tandem. One study focused on faceto-face tandem learning and the other focused on eTandem via e-mail and Skype. The participants of the former were three Japanese-English tandem pairs who participated in a face-to-face tandem project on the campus of a Japanese University. The participants of the latter were three Japanese-German tandem pairs who participated in an eTandem project as part of a collaboration between a Japanese and a German university. These multiple qualitative case studies employed multiple data, including recordings of tandem sessions, learning diaries, resources used in tandem sessions, e-mail/chat logs, field notes, and post-research interviews. The result of the comparison between the two case studies revealed the following three differences affecting the maintenance of learning activities in tandem: 1) distance and physical restriction caused differences in accessibility to sessions, 2) when encountering communication breakdowns, partners in face-to-face tandem learning drew pictures and used nonverbal communication, whereas learners in eTandem tended to rely on online or electronic dictionaries, and 3) learners supported each other more actively in face-to-face tandem learning.

Keywords | Face-to-face tandem learning. eTandem. Motivation. Learner autonomy. CALL.
Resumo | Este artigo comparou dois estudos de casos múltiplos e qualitativos e discutiu a influência que os métodos de tandem face-a-face e de eTandem tiveram na manutenção de atividades de aprendizagem em tandem. Um estudo centrou-se na aprendizagem em tandem face-a-face e o outro centrou-se no eTandem via e-mail e Skype. Os participantes do primeiro grupo eram três duplas de tandem japonês-inglês que participaram do projeto de tandem face-a-face no câmpus de uma universidade japonesa. Os participantes do segundo grupo eram três duplas de tandem japonês-alemão que participaram de um projeto colaborativo de eTandem entre uma universidade japonesa e uma alemã. Esses estudos de casos múltiplos e qualitativos utilizaram dados múltiplos, incluindo gravações de sessões tandem, diários de aprendizagem, recursos usados em sessões tandem, registros de e-mail/ bate-papo, notas de campo e entrevistas pós-pesquisa. O resultado da comparação entre os dois estudos de caso revelou as seguintes três diferenças que afetam a manutenção das atividades de aprendizagem em tandem: 1) a distância e a restrição física causaram diferenças na acessibilidade às sessões; 2) ao encontrar falhas de comunicação, os parceiros de tandem face-a-face desenhavam figuras e usavam comunicação não-verbal, enquanto os aprendizes de eTandem tendiam a contar com dicionários on-line ou eletrônicos; e 3) os alunos se apoiavam mais ativamente na aprendizagem em tandem face-a-face.

Palavras-chave | Aprendizagem em tandem face-aface. eTandem. Motivação. Autonomia do aprendiz. Aprendizagem de línguas mediada por computador.

1 Wakisaka. Kyushu. E-mail: wakisaka.masako.898@m.kyushu-u.ac.jp. ORCID ID: https://orcid.org/00000002-5798-3197 
- Face-to-face tandem and eTandem: differences that influence the maintenance of tandemlearning activities

\section{Introduction}

Brammerts (2005, p. 28-29) defined tandem learning as a learning mode in which two people with different mother tongues work together in order to learn from each other based on the principles of "reciprocity" and "learner autonomy". Reciprocity is a relationship in which two partners help each other in order to improve their abilities and skills, and to accomplish an individual goal. Learner autonomy is the ability to take control of one's own learning. Each of the tandem partners decides what he/she wants to learn, how and when, and what kind of help he/she would like from his/her partner.

Previous research reveals that tandem learning is effective in:

- Improving communicative competence (LEWIS, 2003; BOWER, 2006);

- Developing intercultural competence (STICKLER; LEWIS, 2003);

- Fostering learner autonomy (LITTLE, 2003);

- Increasing motivation (USHIODA, 2000; WAKISAKA,2013);

- Developing confidence in speaking a target language (WAKISAKA, 2012);

- Stimulating motivation to study abroad (OKOCHI, 2011).

\section{Research focus}

This paper discusses how different tandem-learning methods influence maintaining tandem-learning activities. There are roughly two types of tandem learning, face-toface tandem learning and eTandem (see Figure 1). While communication in face-to-face tandem learning is synchronous, communication in eTandem can be asynchronous, quasisynchronous or synchronous. Since 2006, tandem learning via Internet telephone with webcam has been called "Teletandem" (TELLES; VASSALLO, 2006). However, different researchers use other terms, such as video conferencing and telecollaboration. The term "eTandem" is used to refer to tandem learning via the Internet in this paper. 


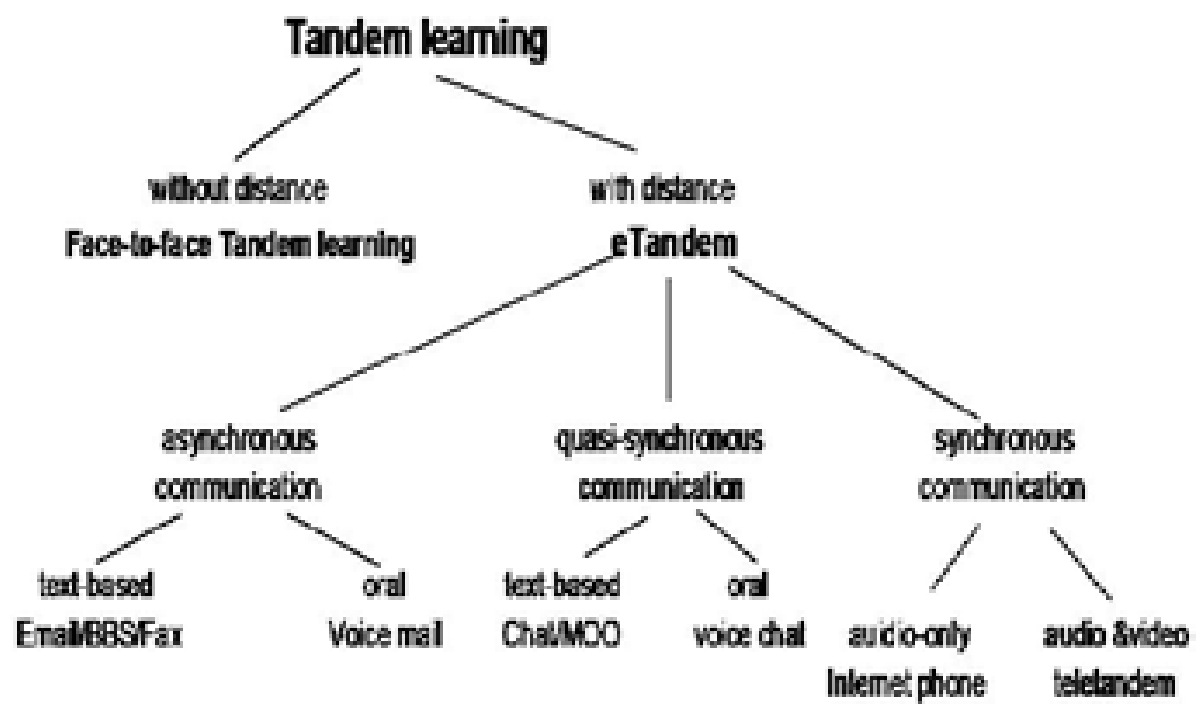

Figure 1. Different types of tandem learning

Normally, it has been said that synchronous eTandem offers advantages that are similar to those of face-to-face tandem learning (BRAMMERTS; CALVERT, 2005). However, it can be difficult for learners to maintain their eTandem activities informally. For example, in a study of an eTandem project at a university in Ireland, Apple and Mullen (2002) found that students exchanged less emails outside of class than in class-3 emails compared to 16.

Motivation has been found to play a large role in a learners' decision to continue tandem activities (USHIODA, 2000; WAKISAKA, 2013). Ushioda (2009) suggests a "personin-context relational view" of motivation, which focuses on real persons, rather than on learners as theoretical abstractions. For Ushioda (2009, p. 220), her focus is on the "agency of the individual person as a thinking, feeling human being, with identity, a personality, a unique history and background, a person with goals, motives and intentions.". Ushioda proposes that researchers need to take "a relational (rather than linear) view of these multiple contextual elements, and view motivation as an organic process that emerges through the complex system of interrelations." (USHIODA, 2011, p. 78). Based on Ushioda's view, two qualitative multiple case studies focusing on real learners in each project were used to try to understand the meaning of the project for each learner. 
- Face-to-face tandem and eTandem: differences that influence the maintenance of tandemlearning activities

\section{Methodology}

Two qualitative research studies were conducted using a multiple case study method to find the factors related to maintaining tandem-learning activities. Case study research investigates a case or cases within a bounded system (CRESWELL, 2007; MERRIAM, 1998; YIN, 1994). Multiple case studies have two stages for analysis. In the first stage, a within-case analysis, the researcher focuses on each case and tries to understand each case deeply. In the second stage, a cross-case analysis, the researcher compares cases and focuses on similarities and differences. In this study, stage three consists of comparing the multiple case studies.

The first multiple case study examined an informal face-to-face tandem learning project on the campus of a Japanese university, and the second multiple case study investigated an extracurricular eTandem project between Japanese university students learning German and German university students learning Japanese. Both projects were organized to give students the opportunity to learn the target language through communication with proficient speakers. The two studies used qualitative methods to explore what/how students learnt through helping each other and how to maintain tandem learning.

\section{Case Studies for Face-to-Face Tandem Learning}

The face-to-face tandem-learning project was an extracurricular activity organized and operated by the author. Participants decided what they would learn and how they would learn it. They were supported by guidelines, coordinator-pair guidance, and networking parties.

\subsection{Participants}

The participants were three English-Japanese tandem pairs (Table 1). Mel, Pat and Arnold were studying Japanese. Mel was an Australian student. Pat was a German student, and Arnold was an Indian researcher. Pat and Arnold were very fluent in English, so they did tandem learning in English. Jun, Masa and Kimura were Japanese students who were studying English through tandem learning. 
Table 1. Participants in multiple case studies for face-to-face tandem learning project

\begin{tabular}{|l|l|l|l|l|l|l|}
\hline Pair & $\begin{array}{l}\text { Name } \\
\text { (Pseudonym) }\end{array}$ & $\mathrm{M} / \mathrm{F}$ & Major & $\begin{array}{l}\text { Target } \\
\text { Language }\end{array}$ & $\begin{array}{l}\text { Mother Tongue } \\
\text { (Other Languages) }\end{array}$ & $\begin{array}{l}\text { Language } \\
\text { Level (CEFR) }\end{array}$ \\
\hline \multirow{2}{*}{ Case 1 } & Mel & $\mathrm{F}$ & Japanese & Japanese & English & B1-B2 \\
\cline { 2 - 7 } & Jun & $\mathrm{M}$ & Science & English & Japanese & B1-B2 \\
\hline \multirow{2}{*}{ Case 2 } & Pat & $\mathrm{M}$ & Robotics & Japanese & German (English) & A2 \\
\cline { 2 - 7 } & Masa & $\mathrm{M}$ & Engineering & English & Japanese & B1 \\
\hline \multirow{2}{*}{ Case 3 } & Arnold & $\mathrm{M}$ & Engineering & Japanese & $\begin{array}{l}\text { Marathi (English, } \\
\text { Bengali and Hindi) }\end{array}$ & A1 \\
\cline { 2 - 7 } & Kimura & $\mathrm{M}$ & Engineering & English & Japanese & A2-B1 \\
\hline
\end{tabular}

\subsection{Data collection}

Multiple qualitative data sets were collected, consisting of

- Recordings of activities (4 sessions)

- Final interviews (after 10 sessions)

- Resources used in the tandem sessions

- Emails to and from coordinator

- Field notes.

\subsection{Summary of each case}

\subsubsection{Case 1: Jun and Mel}

Jun and Mel had tandem sessions every Thursday for 90 minutes. They met at a cafeteria at the university. Mel's study was associated with her graduation thesis about gender equality in the workplace in Japan. She also reviewed and practiced what she learnt in her Japanese classes. On the other hand, Jun often chose to practice topic-based conversations in English and discuss the differences between Australia and Japan. He also practiced for the TOEIC test. They had 12 sessions for four months and continued after the interview until Mel went back to Australia. 
- Face-to-face tandem and eTandem: differences that influence the maintenance of tandemlearning activities

\subsubsection{Case 2. Masa and Pat}

Masa and Pat had tandem sessions once a week for 90 minutes at one of the cafeterias on campus. Masa often talked about his daily life in English because his purpose for tandem was conversing in English. He also learned useful phrases from Pat and practiced presentations for conferences. Pat talked about his daily life and his major and practiced some situations using role-plays. He learned useful phrases and Japanese slangs from Masa. They had 14 sessions over the four months.

\subsubsection{Case 3. Arnold and Kimura}

Arnold and Kimura had tandem sessions once a week for 90 minutes at one of the cafeterias on campus. During the first couple of sessions, Arnold and Kimura role-played daily situations, such as visiting a restaurant or a hospital, and asking directions. After that, they talked about Japanese and Indian culture, such as folklore, foods, old tales and sports. In later sessions, they talked about their daily life. They had 14 sessions over five months.

\section{Case Studies for eTandem}

The eTandem project was a collaboration between a Japanese university and a German university on a voluntary basis. I organized and operated this project along with two coordinators at the German university. Students exchanged e-mails and had Skype sessions from the third week. Table 2 shows topics for each week. This project was supported by guidelines, coordinator-pair guidance, and individual advising if needed.

Table 2. Topics for each week

\begin{tabular}{|l|l|}
\hline Week & Topics \\
\hline 1 & Introducing yourself \\
\hline 2 & Food and drink \\
\hline 3 & Festival and holiday \\
\hline 4 & Culture \\
\hline 5 & Stereotype \\
\hline
\end{tabular}




\subsection{Participants}

The participants were three German-Japanese tandem pairs (Table 3). Nana, Yuko and Aki were Japanese students majoring in German at the Japanese university. David, Charlie and Lea were German students who were learning Japanese in Germany, but during the project period, Charlie was staying in Japan as a researcher.

Table 3. Participants in multiple case studies for eTandem project

\begin{tabular}{|l|l|l|l|l|l|l|}
\hline \multirow{2}{*}{ Pair } & $\begin{array}{l}\text { Name } \\
\text { (Pseudonym) }\end{array}$ & $\mathrm{M} / \mathrm{F}$ & Major & $\begin{array}{l}\text { Target } \\
\text { Language }\end{array}$ & $\begin{array}{l}\text { Mother Tongue } \\
\text { (Other Language) }\end{array}$ & $\begin{array}{l}\text { Language } \\
\text { Level } \\
\text { (CEFR) }\end{array}$ \\
\hline \multirow{2}{*}{ Case 4 } & David & $\mathrm{M}$ & Engineering & Japanese & German (English) & A1- A2 \\
\cline { 2 - 7 } & Nana & $\mathrm{F}$ & German & German & $\begin{array}{l}\text { Japanese (English, } \\
\text { Italian and } \\
\text { Cantonese) }\end{array}$ & A2-B1 \\
\hline \multirow{2}{*}{ Case 5 } & Charlie & $\mathrm{M}$ & Chemistry & Japanese & German (English) & A1- A2 \\
\cline { 2 - 7 } & Yuko & $\mathrm{F}$ & German & German & $\begin{array}{l}\text { Japanese } \\
\text { (English and Italian) }\end{array}$ & A2-B1 \\
\hline \multirow{2}{*}{ Case 6 } & Lea & $\mathrm{F}$ & Scientific & Japanese & German (English) & A1- A2 \\
\cline { 2 - 8 } & Aki & $\mathrm{F}$ & German & German & Japanese (English) & A2-B1 \\
\hline
\end{tabular}

\subsection{Data Collection}

Multiple qualitative data sets were collected, consisting of:

- Interviews after the project period was over

- Questionnaire before interviewing

- Video recordings of two Skype sessions

- Learner diaries

- Chat and email logs with researchers

- Copy of resources used in the tandem sessions

- Field notes. 
- Face-to-face tandem and eTandem: differences that influence the maintenance of tandemlearning activities

\subsection{Summary of each case}

\subsubsection{David and Nana}

David and Nana exchanged 27 e-mails in total and had three Skype sessions during the project period. They wrote and talked about the designated topics. They exchanged the longest e-mails about the culture topic, sharing about their favorite anime, manga and movies. They stopped exchanging e-mails after five weeks but continued holding eTandem sessions via Skype after the project period for more than four months.

\subsubsection{Charlie and Yuko}

Charlie and Yuko exchanged e-mails in both Japanese and German only in the first week. From the second week to fourth week, they wrote only in German and stopped writing e-mails in the fifth week. However, they had Skype sessions more than once a week continuing for longer than one hour. Charlie worked long days in the laboratory in Japan and he did not have chance to speak German. He enjoyed talking in German with Yuko. Yuko tried to use what she learned in her German classes at university when talking with Charlie. He was very helpful and her motivation went up after she started eTandem.

\subsubsection{Case 6. Lea and Aki}

Lea and Aki exchanged 24 e-mails and had three Skype sessions during the project period. They often corrected each other. First, Lea was very excited and eager to communicate with Aki, but she was anxious. Her motivation increased after she found a common interest with Aki, classical music. Aki said that she was so excited about the eTandem project. They both said they enjoyed talking by Skype. However, in the fifth week, Aki stopped responding to e-mails from Lea and their eTandem sessions did not continue. 


\section{Discussion}

The comparison between two multiple case studies showed three differences affecting the maintenance of tandem-learning activities. First, distance and physical restrictions affected learners' accessibility to sessions differently. Participants in face-toface tandem-learning were satisfied with their session times and locations. Mel had classes at three different campuses, so Mel and Jun planned sessions based on Mel's preferences. Masa and Pat were both graduate students who spent much of their days in the laboratory at the university. The cafeteria was very close to their laboratory and easy to access, quiet, and clean. Arnold and Kimura had tandem sessions regularly every Tuesday or Thursday in the cafeteria. However, the learners in eTandem had some difficulties. It was hard for some learners to schedule sessions due to the eight-hour time difference between Germany and Japan during the project. David and Nana continued their eTandem sessions, but Nana had difficulty adjusting her time for the Skype sessions.

(Excerpt-1)

The reason why my motivation decreased is because it became harder to take time for Skype session at night and I had other appointments except for classes during winter holiday. (Interview_Nana)

Learners in eTandem also had difficulty finding a place to use Internet for Skype sessions, as in the cases of Nana and Aki.

(Excerpt-2)

When I stay at my parent's house, it's difficult to concentrate on Skype because others are noisy and I felt uncomfortable talking by Skype because my mother said "You should go to bed" at night. (Chat_Nana)

(Excerpt-3)

[...] I am now at my parent's house. I cannot send emails and use Skype because I don't have Internet access. (I am sending this message from my cell phone.) There is a computer with Internet access in my father's room. But I cannot use it while he is in. [...] Can I tell Lea to cancel the session this week? (Email to coordinator_Aki)

Second, how learners negotiated meaning differed depending on the method of communication. As has been shown in previous studies (e.g., SMITH, 2004), lexical problems triggered most of the negotiation in both face-to-face tandem learning and eTandem in the present studies. However, in face-to-face tandem learning, learners often 
- Face-to-face tandem and eTandem: differences that influence the maintenance of tandemlearning activities

tried to assist by drawing pictures and using gestures to negotiate meaning when their communication broke down. For example, during one session Arnold explained how to cook Indian curry and cheesecake to Kimura in English and Kimura tried to understand it by drawing pictures (Figure 2). In Figure 3, Masa drew an explanation of the Japanese recruiting system based on recommendations from universities.

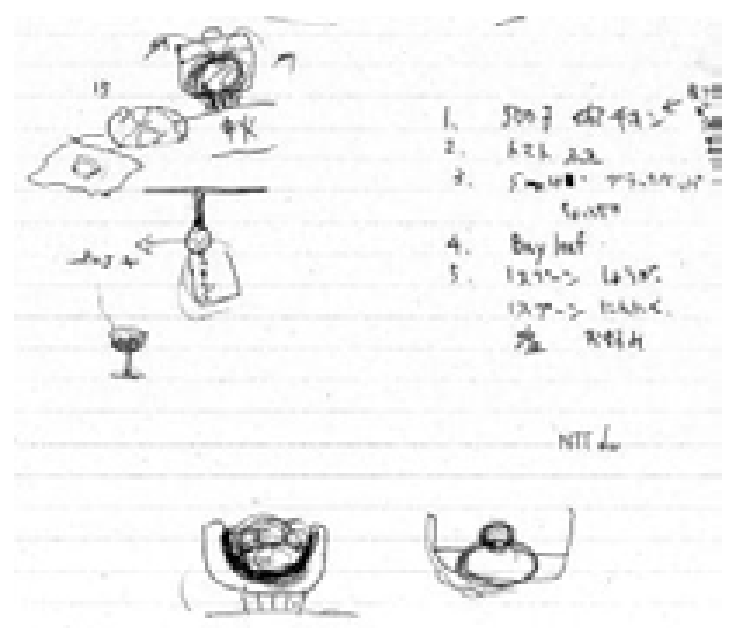

Figure 2. Drawn recipes by Kimura

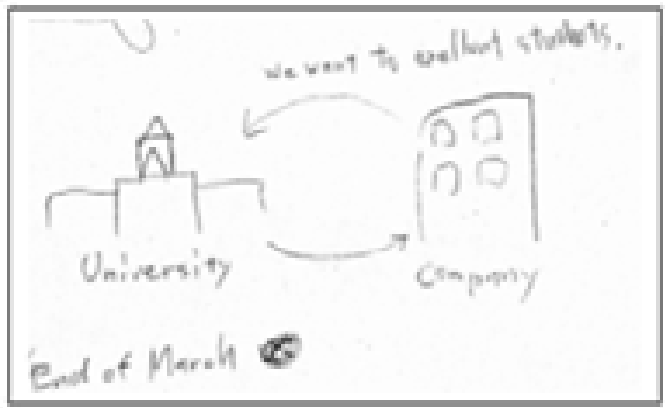

Figure 3. Drawing of Japanese recruiting system by Masa

Another way learners in face-to-face tandem learning negotiated meaning was by continuing to ask their partner until they could understand. These excerpts are from interviews with Masa, Jun, and Mel.

\section{(Excerpt 4)}

When I don't understand well what Pat said [...] I ask him to repeat them many times and I wrote down guessing alphabet which he said on paper and confirm the meaning. I asked Pat to write down the words on the paper. (Interview_Masa)

(Excerpt 5)

I always try to ask what I don't understand because I want Mel to ask me whenever she doesn't understand. (Interview」Jun)

(Excerpt 6)

I asked until I could understand because Jun always taught me. (Interview_Mel) 
On the other hand, learners in eTandem tended to rely first on online or electronic dictionaries when their communication broke down. They often asked their partners to wait while they tried to look up the appropriate words by themselves. When learners were unable to catch a word, they would first ask their partner to write down the word or phrase in the chat window, and then the learner would look it up in a dictionary. Figure 4 shows the search bar of the free online dictionary which Lea often used during her sessions.

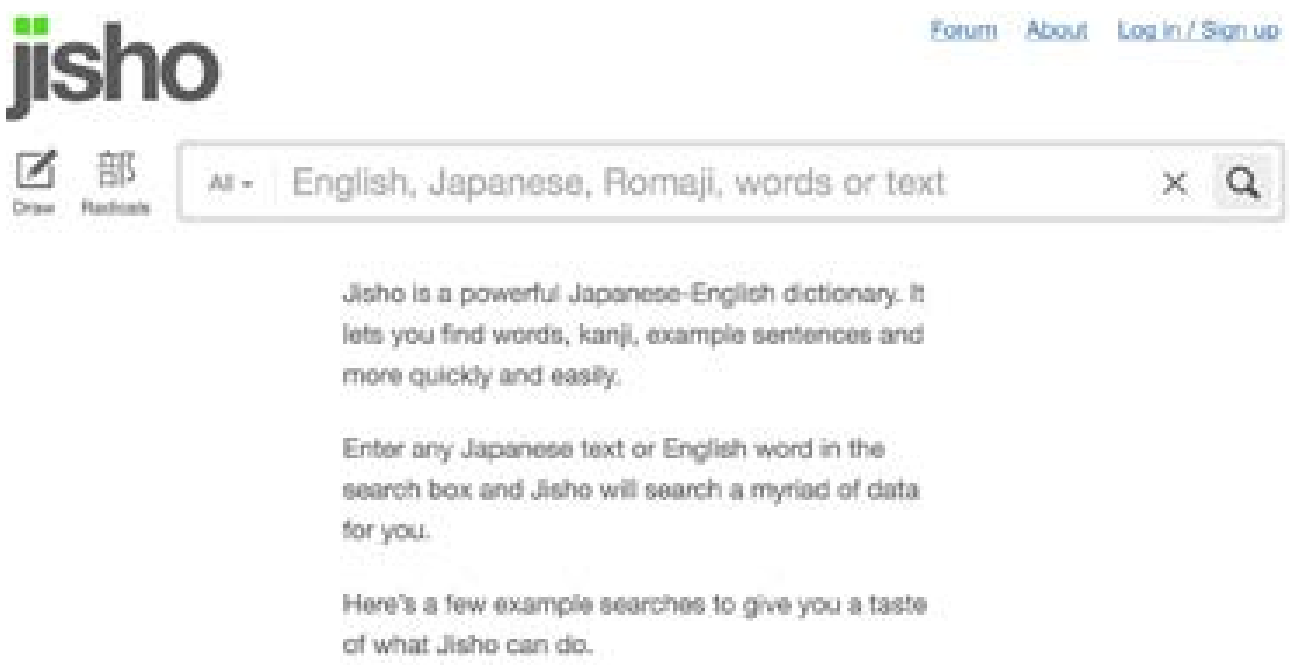

Figure 4. Lea's online dictionary (http://jisho.org)

Yanguas (2009) compared how learners of Spanish negotiated meaning when communication breakdown occurred in different communication media (i.e. audio chat vs. video chat vs. face-to-face chat). It was found that the audio chat group carried out different meaning negotiations from the video chat group because of the lack of visual contact, but the Skype chat and face-to-face chat groups did not differ significantly. However, in the present study, learners in eTandem communicated not only by video chat but also used text chat and other tools such as search engines and online dictionaries at the same time during their Skype sessions. Access to multimodal tools may make a difference in how meaning is negotiated between participants in face-to-face tandem learning and eTandem.

Third, there were differences in attitude of how to support their partner. In faceto-face tandem, active support through careful attention to partners was often observed. All participants in face-to-face tandem learning mentioned how they tried to effectively support their partners. These attempts can be seen in these excerpts from Mel, Arnold, Kimura, and Jun. 
- Face-to-face tandem and eTandem: differences that influence the maintenance of tandemlearning activities

\section{(Excerpt 7)}

In my opinion, mistakes are not so important if you understand the meaning, but I want to correct his English because Jun maybe wants perfect English because he learns English. (Interview_Mel)

\section{(Excerpt 8)}

I try to reduce Kimura's shyness and get him to speak aloud in English [...]. I advised [...] he should speak and repeat aloud. (Interview_Arnold)

\section{(Excerpt 9)}

I paid attention to speaking speed and code switching. I often use many gestures and paraphrase in the sentences which Arnold would understand. (Interview_Kimura)

\section{(Excerpt 10)}

I often pretend to understand even though I couldn't understand when I speak in English. So I could tell by the look on her face when Mel didn't understand, although she said "un, un" ("yes, yes" in Japanese), and I tried to confirm the meaning again. (Interview」Jun)

Moreover, learners in face-to-face tandem sometimes prepared materials for their partners. Figure 5 is an example of Kimura's "present" for his partner, Arnold. Kimura prepared a handout of Japanese tongue twisters because Arnold asked about it in the previous session.

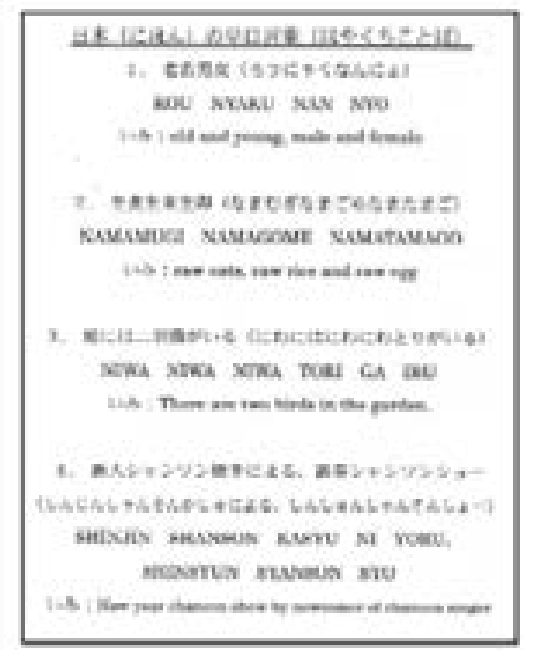

Figure 5. Japanese tongue twisters by Kimura 
On the other hand, learners in eTandem tended to support learners as a response to their partners' explicit requests. The reason may be that learners can get to know their partners more easily in face-to-face tandem than in eTandem because more information is available in face-to-face conversation. In addition, both learners in face-to-face tandem are living in the same culture and they have many topics in common, so it could be easy for them to guess what their partners are trying to say even if the explanations are not clear enough. However, in eTandem learners need to explicitly explain content because they share less common awareness. It is said that Japan is a high context culture, while Germany is a low context culture (HALL, 1976). It might be difficult especially for Japanese learners to make explicit requests, and for their implied requests to be understood. This could be why Aki stopped having sessions, because she was unable to make direct requests to her partner.

\section{Conclusion}

This research compared two qualitative multiple case studies and discussed the influence face-to-face tandem and eTandem methods had on maintaining learning activities in tandem. It was found that there are three differences: 1) distance and physical restriction caused differences in accessibility to sessions, 2) when encountering communication breakdowns, partners in face-to-face tandem learning often drew pictures and used nonverbal communication, whereas learners in eTandem tended to rely first on online or electronic dictionaries, and 3) learners in face-to-face tandem learning supported each other more actively with careful attention.

However, given that the present study is a small-scale exploratory study, there are certain limitations. First, participants in face-to-face tandem learning were EnglishJapanese pairs, while participants in eTandem were German-Japanese pairs. There are potential sociocultural factors (e.g., communication styles, social status in the language, educational experiences with Japanese, etc.) influencing how meaning was negotiated and support was provided to partners. In addition, Japanese participants in eTandem were not familiar with Skype and were not used to communicating with others via the Internet whereas there are more learners familiar with the use of social network service (SNS) now. Those learners may be better at supporting their partner by making excellent use of information technology.

Future studies may investigate case studies in German-Japanese face-to-face tandem learning and English-Japanese eTandem. Notwithstanding the limitations, findings from the present study may have some important pedagogical measures that coordinators 
- Face-to-face tandem and eTandem: differences that influence the maintenance of tandemlearning activities

can take when organizing and managing eTandem projects. First, coordinators should take into consideration that the time difference may influence one side of the pairs more than the other. They also should confirm whether pairs have enough time and can secure a place for Skype sessions when pairing. Second, coordinators should suggest that supporting each other actively is very important and show how to effectively manage communication breakdown. Third, coordinators should suggest to Japanese learners to explicitly express their preferences to their partners. In particular, it is more polite to say no when the learner does not want to do something rather than just saying yes and trying to adjust to an undesirable situation. Finally, they should encourage tandem partners to say what they want directly and negotiate with their partner.

\section{References}

APPEL, C.; MULLEN, T. A new tool for teachers and researchers involved in e-mail tandem language learning. ReCALL, v. 14, n. 2, p. 195-208, 2002.

BOWER, J. Learner strategies in tandem language learning via synchronous computer mediated communication. The Journal of Kanda University of International Studies, v. 18, p. 335-358, 2006.

BRAMMERTS, H. Autonomes Sprachenlernen im Tandem: Entwicklung eines Konzepts. In: BRAMMERTS, H.; KEPPLIN, K. (Eds.). Selbstgesteuertes sprachenlernen im tandem (Ein handbuch 2. Auflage). Tübingen, Germany: Stauffenburg, 2005. p. 9-16. (Original work published 2001)

BRAMMERTS, H.; CALVERT, M. Lernen durch Kommunizieren im Tandem. In: BRAMMERTS, H.; KEPPLIN, K. (Eds.). Selbstgesteuertes sprachenlernen im tandem (Ein handbuch 2. Auflage). Tübingen: Stauffenburg, 2005. p. 27-38. (Original work published 2001)

CRESWELL, J. W. Qualitative inquiry and research design: Choosing among five approaches. Thousand Oaks, CA: Sage, 2007.

HALL, T. E. Beyond culture. Anchor, 1976.

LEWIS, T. The case for tandem learning. In: LEWIS, T.; WALKER, L. (Eds.). Autonomous language learning in tandem. Sheffield, UK: Academy electronic publications, 2003. p. 13-25. 
LITTLE, D. Tandem language learning and learner autonomy. In: LEWIS, T.; WALKER, L. (Eds.). Autonomous language learning in tandem. Sheffield, UK: Academy electronic publications, 2003. p. 37-44.

MERRIAM, S. B. Qualitative research and case study applications in education. New York, NY: John Wiley \& Sons, 1998.

OKOCHI, T. Tandemu purojekuto no jissenhoukoku: Koosusekkei to sono seika [Report on Tandem project: Couse design and the results]. Mie University Scholarly E-collections, v.19, p.1-6,2011. Availablein:http://miuse.mie-u.ac.jp/bitstream/10076/11717/1/75C15085. pdf. Access 12 Aug. 2018.

SMITH, B. Computer-mediated negotiated interaction and lexical acquisition. SSLA, v. 26, p. 365-398, 2004.

STICKLER, U.; LEWIS, T. Tandem learning and intercultural competence. In: LEWIS, T.; WALKER, L. (Eds.). Autonomous language learning in tandem. Sheffield, UK: Academy electronic publications, 2003. p. 93-104.

TELLES, J. A.; VASSALLO, M. L. Foreign language learning in-tandem: Teletandem as an alternative proposal in CALLT. The ESPecialist, v. 27, n. 2, p. 189-212, 2006.

USHIODA, E. Tandem language learning via e-mail: From motivation to autonomy. ReCALL, v. 12, n. 2, p. 121-128, 2000.

USHIODA, E. A person-in-context relational view of emergent motivation, self and identity. In: DÖRNYEI, Z.; USHIODA, E. (Eds.). Motivation, language identity and the $\mathbf{L} 2$ self. Bristol, UK: Multilingual Matters, 2009. p. 215-228.

WAKISAKA, M. How tandem learning changes attitude towards learning English: A case study of a Japanese learner. Paper presented at the Independent Learning Association 2012 Conference. Victoria University of Wellington, 2012, August.

WAKISAKA, M. Etandemu ni oite doitujin nihongogakushuusha no douki o henka saseta youin [Factors that influenced the motivation of a German learner of Japanese in eTandem.] Handai nihongo kenkyuu, v. 25, p. 105-135, 2013.

YANGUAS, I. Multimedia glosses and their effect on L2 text comprehension and vocabulary learning, Language learning \& technology, v. 13, n. 2, p. 48-67, 2009.

YIN, R. K. Case study research: Design and methods. (2nd ed.). Thousand Oaks, CA: Sage, 1994. 
- Face-to-face tandem and eTandem: differences that influence the maintenance of tandemlearning activities

COMO CITAR ESTE ARTIGO: WAKISAKA, Masako. Face-to-face tandem and etandem: differences that influence the maintenance of tandem learning activities. Revista do GEL, v. 15, n. 3, p. 42-57, 2018. Disponível em: https://revistadogel.gel.org.br/

DOI: http://dx.doi.org/10.21165/gel.v15i3.2408

Submetido em: 14/11/2018 | Aceito em: 17/12/2018. 